\title{
Cancer incidence attributable to tobacco in Alberta, Canada, in 2012
}

\author{
Abbey E. Poirier MSc, Anne Grundy PhD, Farah Khandwala MSc, Sierra Tamminen, \\ Christine M. Friedenreich PhD, Darren R. Brenner PhD
}

\section{Abstract}

Background: Strong and consistent epidemiologic evidence shows that tobacco smoking causes cancers at various sites. The purpose of this study was to quantify the proportion and total number of site-specific cancers in Alberta attributable to tobacco exposure.

Methods: The proportion of incident cancer cases attributable to active and passive tobacco exposure in Alberta was estimated with population attributable risks. Data from the Canadian Community Health Survey (CCHS) for 2000-2007 were used to estimate prevalence of active (current or former smoker) and passive (second-hand smoke) tobacco exposure in Alberta.

Results: According to the 2000/01 CCHS, 29.1\% and 38.6\% of Albertans were estimated to be current and former smokers, respectively. According to the 2003 CCHS, $23.7 \%$ of Albertans who had never smoked reported regular second-hand exposure to tobacco. Population attributable risk estimates for tobacco-related cancer sites ranged from about $4 \%$ for ovarian cancer to $74 \%$ for laryngeal cancer. About $5 \%$ of incident lung cancers in men and women who never smoked could be attributed to passive tobacco exposure. Overall, $37.0 \%$ of tobacco-related cancers in Alberta (or $15.7 \%$ of all cancers) were estimated to be attributable to active tobacco smoking in 2012.

Interpretation: A notable proportion of cancers associated with tobacco use were estimated to be attributable to active smoking in Alberta. Strategies to reduce the prevalence of active tobacco smoking in Alberta could have a considerable impact on future cancer incidence.

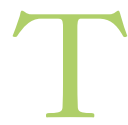
here is sufficient evidence from multiple meta-analyses, cohort and case-control studies to conclude that active tobacco smoking is associated with an increased risk of cancers of the lung, larynx, oral cavity and pharynx, paranasal sinuses, esophagus, stomach, pancreas, liver, kidney, ureter, bladder, uterine cervix, bone marrow (myeloid leukemia) ovary, colon and rectum, as determined by the International Agency for Research on Cancer. ${ }^{1}$ In 2012, the International Agency for Research on Cancer determined that there was sufficient human evidence to conclude that residential and occupational passive tobacco exposures are both lung cancer carcinogens. The monograph included results from a meta-analysis of 55 studies by Taylor and colleagues, ${ }^{2}$ which reported a relative risk (RR) of 1.27 for lung cancer in never smoking women exposed to second-hand smoke from their spouse. In a more recent pooled analysis of 18 case-control studies, the RR of lung cancer in male and female never smokers exposed to second-hand smoke at home was $1.19 .{ }^{3}$ Results were inconsistent for all other cancer sites considered.
Based on these consistent associations, the purpose of this study was to estimate the population attributable risk and subsequently the proportion of cancers attributable to each of active and passive tobacco exposure in the general population in Alberta, Canada.

\section{Methods}

Detailed methods on the data abstraction and population attributable risk calculations for the current study were previ-

Competing interests: None declared.

This article has been peer reviewed.

Correspondence to: Darren Brenner, darren.brenner@ albertahealthservices.ca

CMAJ Open 2016. DOI:10.9778/cmajo.20150069 
ously published. ${ }^{4}$ In determining the population attributable risks for tobacco exposure and cancer in Alberta, separate methods were used for active and passive tobacco exposures, because the risk of cancer and the associated cancer sites differ between these 2 types of tobacco exposure. As stated in the detailed methods for this study, ${ }^{4}$ for both active and passive tobacco exposure, we extracted risk estimates from a review of reports from both international collaborative panels and published peer-reviewed literature.

\section{Active tobacco exposure}

\section{Latency period}

The effect of tobacco smoking on cancer risk is understood to be the result of past exposure. Therefore, a biologically meaningful latency period was identified from the literature for both active and passive tobacco exposures. As we have previously described, ${ }^{4}$ to quantify this latency period, we distinguish between the theoretical latency period (the time between initiation of exposure and cancer diagnosis) and the measured latency period (the time between exposure measurement and cancer diagnosis). To select the appropriate tobacco exposure prevalence data for the analyses presented in this paper, we attempted to quantify the measured latency period and will refer to this simply as the latency period. To quantify this latency period we used the average time between exposure measurement and cancer diagnosis obtained from high-quality cohort studies. As previously described in this series, ${ }^{4}$ the cycle of the Canadian Community Health Survey (CCHS) used corresponded to the midpoint of the latency period suggested by cohort studies for each cancer site of interest. Latency periods and corresponding CCHS cycles used for each cancer site of interest are presented in Table 1..$^{5-35}$

\section{Prevalence of exposure}

Data from the CCHS were obtained online through the Statistics Canada data portal ${ }^{36}$ for active tobacco prevalence estimates. The population-based cross-sectional CCHS is used to collect information on the health status, health care use and health determinants of Canadians. Details of the methods used for the CCHS were published previously. ${ }^{37}$ Although the CCHS does not capture information on Aboriginal Canadians living on reserves or people living on military facilities or crown land, the CCHS sampling frame is representative of $96 \%-98 \%$ of the adult Canadian population. In the 2000/01 cycle, 130000 respondents aged 12 years and older were interviewed after being selected using a multistage sample allocation strategy based on both the population size and number of health regions in each province and territory. The survey methods have been described previously. ${ }^{37}$ Information on 2 types of active smoking in Alberta was used for the current study. In the CCHS, current smokers are defined as those who smoked cigarettes daily or occasionally at the time of the interview, whereas former smokers are those who did not smoke at the time of the interview and had smoked more than 100 cigarettes in their lifetime. Never smokers are defined as those who did not smoke at the time of the interview and had smoked fewer than 100 cigarettes in their lifetime.

\section{Statistical analyses}

Population attributable risk estimation: To estimate the population attributable risk for active tobacco smoking, the following equation, previously used by both Parkin ${ }^{38}$ and Cancer Care Ontario $^{39}$ was used here:

Population attributable risk $=\left(P_{e 1} \times \mathrm{ERR}_{1}\right)+\left(P_{c 2} \times \mathrm{ERR}_{2}\right) / 1+$ $\left[\left(P_{e l} \times \mathrm{ERR}_{1}\right)+\left(P_{c 2} \times \mathrm{ERR}_{2}\right)\right]$

Where $P_{c l}$ is the prevalence of current active tobacco smokers, $P_{c 2}$ is the prevalence of former active tobacco smokers, $\mathrm{ERR}_{1}$ is the excess RR (RR - 1) of cancer in current smokers compared with never smokers and $\mathrm{ERR}_{2}$ is the ERR of cancer in former smokers compared with never smokers.

To estimate $95 \%$ confidence intervals around population attributable risk estimates, Monte Carlo simulation methods were used wherein the relative risk estimates were drawn from a $\log$ normal distribution, prevalence estimates were drawn from a binomial distribution and incidence estimates were drawn from a Poisson distribution. Parameters for the distributions were defined by reported point estimates and confidence intervals (CIs); 10000 samples were drawn and the 2.5th and 97.5 th percentiles of the resulting population attributable risk distribution were used as the lower and upper limits of a $95 \%$ CI. Similar techniques were used by two previous studies that estimated population attributable risk. ${ }^{40,41}$ These estimations were performed for individual sex and age groups.

\section{Cancer attributable to active smoking}

To determine the number of cancer cases attributable to active smoking in Alberta in 2012, incidence data for each cancer type were obtained from the Alberta Cancer Registry. The population attributable risk was then multiplied by the number of incident cancers in each age group for the year 2012 to estimate the number of attributable cancers. A lag time of either 5 or 10 years, depending on the cancer site, was applied to the age groups used in the cancer incidence data to account for the fact that cancers diagnosed in 2012 were attributable to past rather than current exposure levels. The appropriate latency period was assessed for each cancer type as described above and then rounded to a lag time of either 5 or 10 years to reduce the variation in age groups used for this analysis.

\section{Passive tobacco exposure}

\section{Latency period}

A biologically plausible latency period between passive tobacco exposure and lung cancer was determined from the literature. The CCHS cycle 2.1 (2003) was used to correspond to the midpoint of latency periods suggested by previous cohort studies (Table 1).

\section{Prevalence of exposure}

Data on the prevalence of passive smoking in never smokers was also available from the CCHS. ${ }^{36}$ In the survey, passive smokers were defined as those who were regularly exposed to tobacco smoke in their home, a vehicle or a public place. 


\section{OPEN}

Research

\section{Statistical analyses}

Population attributable risk calculation: The following equation was used to calculate the population attributable risk for lung cancer and passive tobacco smoke exposure in never smokers:
Population attributable risk $=P_{e}(\mathrm{RR}-1) / 1+\left[P_{e}(\mathrm{RR}-1)\right]$

Where $P_{e}$ is the prevalence of passive tobacco exposure and $\mathrm{RR}$ is the RR of lung cancer in people passively exposed to tobacco smoke compared with those never exposed.

Table 1: Predetermined latency periods by cancer site and cycle of prevalence data used for population attributable risk calculations

\begin{tabular}{|c|c|c|c|}
\hline Exposure; cancer site & $\begin{array}{l}\text { Latency period } \\
\text { (range, yr) }\end{array}$ & Source & Corresponding CCHS cycle (yr) \\
\hline \multicolumn{4}{|l|}{ Active tobacco } \\
\hline Lung & $7-33$ & $\begin{array}{l}\text { Boffetta and colleagues } 2006^{5} \\
\text { Kenfield and colleagues } 2008^{6} \\
\text { Freedman and colleagues } 2008^{7} \\
\text { Yun and colleagues } 2005^{8}\end{array}$ & $1.1(2000 / 01)$ \\
\hline Oral cavity and pharynx & $4-26$ & $\begin{array}{l}\text { Boffetta and colleagues } 2006^{5} \\
\text { Friborg and colleagues } 2007^{9} \\
\text { Nordlund and colleagues } 1997^{10}\end{array}$ & $1.1(2000 / 01)$ \\
\hline Larynx & $4-9$ & $\begin{array}{l}\text { Jee and colleagues } 2004^{11} \\
\text { Freedman and colleagues } 2007^{7} \\
\text { Yun and colleagues } 2005^{8}\end{array}$ & $3.1(2005)$ \\
\hline Esophagus & $9-15$ & $\begin{array}{l}\text { Tran and colleagues } 2004^{12} \\
\text { Jee and colleagues } 2004^{11} \\
\text { Ishiguro and colleagues } 2009^{13}\end{array}$ & $1.1(2000 / 01)$ \\
\hline Stomach & $6-8$ & $\begin{array}{l}\text { Jee and colleagues } 2004^{11} \\
\text { Lindblad and colleagues } 2005^{14} \\
\text { Sung and colleagues } 2007^{15}\end{array}$ & $3.1(2005)$ \\
\hline Liver & $5-26$ & $\begin{array}{l}\text { Yang and colleagues } 2002^{16} \\
\text { Nordlund and colleagues } 1997^{10} \\
\text { Basa and colleagues } 1977^{17}\end{array}$ & $1.1(2000 / 01)$ \\
\hline Pancreas & $6-23$ & $\begin{array}{l}\text { Nordlund and colleagues } 1997^{10} \\
\text { Friedman and van den Eeden } 1993^{18}\end{array}$ & $1.1(2000 / 01)$ \\
\hline Colon-rectum & $9-13$ & $\begin{array}{l}\text { Tsoi and colleagues } 2009^{19} \\
\text { Jee and colleagues } 2004^{11} \\
\text { Hannan and colleagues } 2009^{20}\end{array}$ & $1.1(2000 / 01)$ \\
\hline Ovary & $13-23$ & $\begin{array}{l}\text { Terry and colleagues } 2003^{21} \\
\text { Tworoger and colleagues } 2008^{22} \\
\text { Gram and colleagues } 2008^{23}\end{array}$ & $1.1(2000 / 01)$ \\
\hline Cervix & $2-10$ & $\begin{array}{l}\text { Kapeu and colleagues } 2009^{24} \\
\text { Mclntyre-Seltman and colleagues } 2005^{25} \\
\text { Schiffman and colleagues } 1993^{26}\end{array}$ & $4.1(2007)$ \\
\hline Kidney & $16-27$ & $\begin{array}{l}\text { Chow and colleagues } 2000^{27} \\
\text { Engeland and colleagues } 1996^{28} \\
\text { Nordlund and colleagues } 1997^{10}\end{array}$ & $1.1(2000 / 01)$ \\
\hline Bone marrow (myeloid leukemia) & $19-26$ & $\begin{array}{l}\text { Fernberg and colleagues } 2007^{29} \\
\text { Nordlund and colleagues } 1997^{10} \\
\text { Engeland and colleagues } 1996^{28}\end{array}$ & $1.1(2000 / 01)$ \\
\hline Bladder & $3-26$ & $\begin{array}{l}\text { Alberg and colleagues } 2007^{30} \\
\text { Tulinius and colleagues } 1997^{31} \\
\text { Nordlund, } 1997^{10} \\
\text { Yuan and colleagues } 1996^{32}\end{array}$ & $1.1(2000 / 01)$ \\
\hline \multicolumn{4}{|l|}{ Passive tobacco } \\
\hline Lung & $6-13$ & $\begin{array}{l}\text { Veglia and colleagues } 2007^{33} \\
\text { Vineis and colleagues } 2005^{34} \\
\text { Kurahashi and colleagues } 2008^{35}\end{array}$ & $2.1(2003)$ \\
\hline
\end{tabular}




\section{Cancer attributable to active smoking}

To estimate the number of cases of lung cancer attributable to passive tobacco exposure, an approximation of $10 \%$ of incident lung cancer cases in 2012 from the Alberta Cancer Registry was used to represent the proportion of lung cancer occurring in never smokers. ${ }^{42}$ The population attributable risk was then multiplied by this number to determine the number of lung cancer cases attributable to passive tobacco smoke exposure in Alberta. A process similar to that described for active tobacco exposure was used to adjust the age groups for the cancer incidence data to account for cancers caused by past exposures to passive tobacco smoke.

\section{Results}

\section{Active tobacco exposure}

\section{Prevalence of active tobacco exposure}

Data from several cycles of the CCHS (2000-2007) were used to estimate population attributable risks for active tobacco exposure depending on the cancer site. However, here we present the prevalence estimates only from the 2000/01 cycle, because these data were used for most cancer sites.

Data from the CCHS estimated that in 2000/01, between $12.9 \%$ (95\% CI $10.9 \%-14.9 \%$ ) and $35.4 \%$ (95\% CI $33.0 \%-$ $37.7 \%$ ) of Albertans were current smokers and between $28.4 \%$ (95\% CI $26.4 \%-30.5 \%$ ) and $52.2 \%$ (95\% CI 49.4\%$55.0 \%$ ) were former smokers (Table 2). For all age groups, the prevalence of current smokers was higher in men than in women. This higher prevalence among men was also observed for the prevalence of former smokers, with the exception of the 20-34 year age group, where the prevalence was comparable between sexes. The prevalence of current smokers decreased with increasing age for both sexes. In contrast, the prevalence of former smokers increased with increasing age (Table 2). Using data from the populationbased Alberta Tomorrow Project, ${ }^{41}$ we conducted a sensitivity analysis to determine the prevalence of Albertans smoking tobacco products other than cigarettes. In 2008, about $0.1 \%$, $0.09 \%$ and $0.42 \%$ of Albertans were daily smokers of cigars, pipes and cigarillos, respectively (data not shown).

\section{Risk estimates}

For current and former smokers, the RRs of cancer developing at various sites and the sources for these estimates are shown in Table 3., ${ }^{3,19,43,44}$ Most of the risk estimates used in this study were taken from a meta-analysis of 216 studies published by Gandini and colleagues. ${ }^{43}$ The RRs from large meta-analyses published by Tsoi and colleagues ${ }^{19}$ and the Collaborative Group on Epidemiological Studies of Ovarian Cancer ${ }^{44}$ were used for colorectal and ovarian cancers, respectively.

\section{Population attributable risk results}

Population attributable risk estimates and numbers of observed and excess attributable cancer cases for each age group by sex and combined sexes for active tobacco smoking are presented in Table 4. Measures of uncertainty (95\% CIs)

Table 2: Prevalence of current smokers, former smokers and passive smokers in Alberta

Prevalence $(95 \% \mathrm{Cl})$

\begin{tabular}{|c|c|c|c|}
\hline \multirow[b]{2}{*}{ Age, yr } & \multicolumn{3}{|c|}{ Prevalence $(95 \% \mathrm{Cl})$} \\
\hline & Current smokers* & Former smokers ${ }^{*}$ & Any passive tobacco exposure $†$ \\
\hline \multicolumn{4}{|l|}{ Men } \\
\hline 20-34 & $39.5(36.1-42.9)$ & $28.3(25.5-31.2)$ & $39.0(33.7-44.3)$ \\
\hline $35-44$ & $34.4(30.8-37.9)$ & $38.3(35.0-41.7)$ & $25.3(20.3-30.3)$ \\
\hline $45-64$ & $28.9(25.9-31.9)$ & $49.1(45.5-52.6)$ & $20.9(15.3-26.4)$ \\
\hline$\geq 65$ & $13.5(10.5-16.5)$ & $68.5(64.2-72.7)$ & $11.1(6.5-15.7)$ \\
\hline \multicolumn{4}{|l|}{ Women } \\
\hline $20-34$ & $31.0(27.7-34.2)$ & $28.5(25.7-31.4)$ & $26.0(21.9-30.2)$ \\
\hline $35-44$ & $29.7(26.4-33.1)$ & $35.1(31.9-38.3)$ & $20.8(15.6-26.0)$ \\
\hline $45-64$ & $26.0(23.2-28.8)$ & $40.1(36.9-43.3)$ & $14.4(10.7-18.2)$ \\
\hline$\geq 65$ & $12.4(9.9-14.9)$ & 38.7 (35.1-42.3) & $11.4(8.2-14.6)$ \\
\hline \multicolumn{4}{|l|}{ Total } \\
\hline $20-34$ & $35.4(33.0-37.7)$ & $28.4(26.4-30.5)$ & $32.3(28.9-35.8)$ \\
\hline $35-44$ & $32.1(29.6-34.6)$ & $36.7(34.3-39.1)$ & $23.0(19.4-26.6)$ \\
\hline $45-64$ & $27.5(25.4-29.5)$ & $44.6(42.3-47.0)$ & $17.0(13.8-20.1)$ \\
\hline$\geq 65$ & $12.9(10.9-14.9)$ & $52.2(49.4-55.0)$ & $11.3(8.7-13.9)$ \\
\hline
\end{tabular}


for the population attributable risk estimates can be found in Appendix 1 (available at www.cmajopen.ca/content/4/4/E578/ suppl/DC1). In 2012, an estimated 2485 incident cancer cases were be attributable to active smoking. This number of cases was $37.0 \%$ of cancers known to be associated with active smoking and $15.7 \%$ of all incident cancers in 2012 (Table 5). Lung cancer accounted for more than half of the excess cases, with 739 cases in men and 733 cases in women. The second greatest contributor to the number of excess cases was colorectal cancer, with 141 excess cases in men and 85 excess cases in women. Although the population attributable risk estimates for colorectal cancer were relatively low, the number of excess cases was high because of the large number of incident colorectal cancer cases in Alberta in 2012. With the exceptions of pancreatic cancer, the overall burden of attributable cancer cases was greater among men than among women.

\section{Passive tobacco exposure}

\section{Prevalence of passive tobacco exposure}

Between 11.3\% (95\% CI 8.7\%-13.9\%) and 32.3\% (95\% CI $28.9 \%-35.8 \%)$ of Albertan never smokers were regularly

\begin{tabular}{|c|c|c|c|c|}
\hline \multirow[b]{2}{*}{ Exposure; cancer site } & \multirow{2}{*}{$\begin{array}{l}\text { Period of } \\
\text { exposure }\end{array}$} & \multicolumn{3}{|c|}{$\mathrm{RR}(95 \% \mathrm{Cl})$} \\
\hline & & Men & Women & All \\
\hline \multicolumn{5}{|l|}{ Active tobacco } \\
\hline \multirow[t]{2}{*}{ Lung* } & Current & $9.9(6.8-14.2)$ & $7.6(5.4-10.7)$ & $9.0(6.70-12.1)$ \\
\hline & Former & - & - & $3.8(2.8-5.3)$ \\
\hline \multirow[t]{2}{*}{ Oral cavity and pharynx* } & Current & - & - & $3.6(2.6-4.8)$ \\
\hline & Former & - & - & $1.2(0.7-1.9)$ \\
\hline \multirow[t]{2}{*}{ Larynx* } & Current & - & - & $7.0(3.1-15.5)$ \\
\hline & Former & - & - & $4.6(3.4-6.4)$ \\
\hline \multirow[t]{2}{*}{ Esophagus* } & Current & $2.52(1.8-3.5)$ & $2.3(1.5-3.4)$ & $2.5(2.0-3.1)$ \\
\hline & Former & - & - & $2.0(1.8-2.3)$ \\
\hline \multirow[t]{2}{*}{ Stomach* } & Current & $1.7(1.5-2.1)$ & $1.4(1.2-1.8)$ & $1.6(1.4-2.0)$ \\
\hline & Former & - & - & $1.3(1.2-1.5)$ \\
\hline \multirow[t]{2}{*}{ Liver* } & Current & $1.8(1.2-2.8)$ & $1.5(1.1-2.0)$ & $1.6(1.3-1.9)$ \\
\hline & Former & - & - & $1.5(1.1-2.1)$ \\
\hline \multirow[t]{2}{*}{ Pancreas* } & Current & $1.6(1.3-2.0)$ & $1.7(1.3-2.3)$ & $1.7(1.5-1.9)$ \\
\hline & Former & - & - & $1.2(1.0-1.3)$ \\
\hline \multirow[t]{2}{*}{ Colon-rectum $†$} & Current & $1.4(1.2-1.6)$ & $1.1(1.0-1.1)$ & $1.2(1.1-1.3)$ \\
\hline & Former & $1.2(1.1-1.4)$ & $1.2(1.1-1.3)$ & $1.2(1.1-1.2)$ \\
\hline \multirow[t]{2}{*}{ Ovary } & Current & - & $1.1(1.0-1.1)$ & - \\
\hline & Former & - & $1.1(1.0-1.1)$ & - \\
\hline \multirow[t]{2}{*}{ Cervix $^{*}$} & Current & - & $2.2(1.1-4.4)$ & - \\
\hline & Former & - & $1.3(1.1-1.4)$ & - \\
\hline \multirow[t]{2}{*}{ Kidney* } & Current & $1.6(1.3-1.9)$ & $1.4(1.0-1.7)$ & $1.5(1.3-1.7)$ \\
\hline & Former & - & - & $1.2(1.1-1.4)$ \\
\hline \multirow[t]{2}{*}{ Myeloid leukemia* } & Current & - & - & $1.1(0.7-1.7)$ \\
\hline & Former & - & - & $1.3(0.3-5.8)$ \\
\hline \multirow[t]{2}{*}{ Bladder* $^{*}$} & Current & $2.8(2.0-3.9)$ & $2.7(1.8-4.1)$ & $2.8(2.2-3.5)$ \\
\hline & Former & - & - & $1.7(1.5-2.0)$ \\
\hline \multicolumn{5}{|l|}{ Passive tobacco } \\
\hline Lung§ & Ever exposed & - & - & $1.34(1.24-1.45)$ \\
\hline \multicolumn{5}{|c|}{$\begin{array}{l}\text { Note: } \mathrm{Cl}=\text { confidence interval, } \mathrm{RR}=\text { relative risk. } \\
{ }^{*} \text { Estimates from Gandini and colleagues. }{ }^{43} \\
\text { †Estimates from Tsoi and colleagues. }{ }^{19} \\
\text { fEstimates from the Collaborative Group on Epidemiological Studies of Ovarian Cancer. }{ }^{44} \\
\text { §Estimates from Kim and colleagues. }{ }^{4}\end{array}$} \\
\hline
\end{tabular}




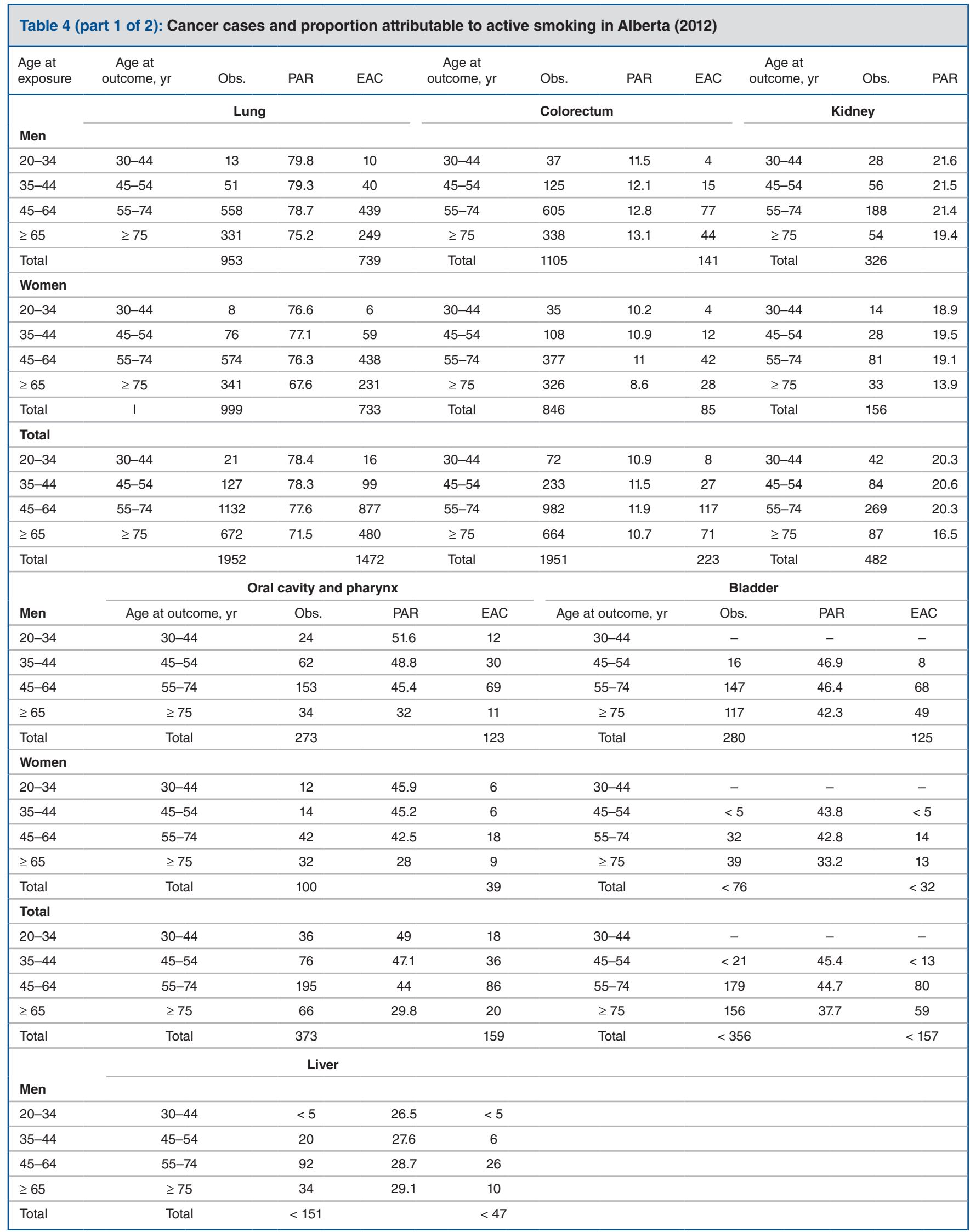




\begin{tabular}{|c|c|c|c|c|c|c|c|c|}
\hline $\begin{array}{l}\text { Age at } \\
\text { exposure, yr }\end{array}$ & Age at outcome, yr & Obs. & PAR & EAC & Age at outcome, yr & Obs. & PAR & EAC \\
\hline & \multicolumn{4}{|c|}{ Liver } & \multicolumn{4}{|c|}{ Ovary } \\
\hline \multicolumn{9}{|l|}{ Women } \\
\hline $20-34$ & $30-44$ & $<5$ & 23.9 & $<5$ & $30-44$ & 15 & 3.4 & 1 \\
\hline $45-64$ & $55-74$ & 43 & 25.5 & 11 & $55-74$ & 85 & 3.8 & 3 \\
\hline$\geq 65$ & $\geq 75$ & 18 & 20.6 & 4 & $\geq 75$ & 48 & 3 & 1 \\
\hline Total & Total & $<72$ & & $<22$ & Total & 189 & & 7 \\
\hline \multicolumn{9}{|l|}{ Total } \\
\hline $20-34$ & $30-44$ & $<5$ & 25.2 & 1 & $30-44$ & 15 & 3.4 & 1 \\
\hline Total & Total & $<218$ & & 57 & Total & 189 & & 7 \\
\hline & \multicolumn{4}{|c|}{ Myeloid leukemia } & \multicolumn{4}{|c|}{ Cervix } \\
\hline \multicolumn{9}{|l|}{ Men } \\
\hline $20-34$ & $30-44$ & 10 & 10.1 & 1 & & & & \\
\hline $35-44$ & $45-54$ & 15 & 11.8 & 2 & & & & \\
\hline $45-64$ & $55-74$ & 47 & 13.7 & 6 & & & & \\
\hline$\geq 65$ & $\geq 75$ & 27 & 16.5 & 4 & & & & \\
\hline Total & Total & 99 & & 14 & & & & \\
\hline \multicolumn{9}{|l|}{ Women } \\
\hline $20-34$ & $30-44$ & 19 & 9.8 & 2 & $25-39$ & 49 & 25.3 & 12 \\
\hline $35-44$ & $45-54$ & 28 & 11.3 & 3 & $40-49$ & 30 & 28.3 & 8 \\
\hline $45-64$ & $55-74$ & 74 & 12.7 & 9 & $50-69$ & 38 & 27.7 & 11 \\
\hline$\geq 65$ & $\geq 75$ & 55 & 13.2 & 7 & $\geq 70$ & 15 & 18.3 & 3 \\
\hline Total & Total & 176 & & 22 & Total & 132 & & 34 \\
\hline
\end{tabular}

exposed to passive tobacco smoke in 2003 (Table 2). Among people 65 years of age and older, prevalence estimates were comparable between sexes. For all other age groups, the prevalence of passive tobacco exposure was higher for men than for women. Prevalence of passive tobacco exposure decreased with increasing age for both men and women (Table 2).

\section{Risk estimates}

A pooled analysis of 18 case-control studies in the International Lung Cancer Consortium by Kim and colleagues ${ }^{3}$ was used to obtain the risk estimate for the association between passive exposure to tobacco smoke and lung cancer (Table 3).

\section{Population attributable risk results}

The population attributable risks and the numbers of observed and excess attributable lung cancer cases for each age group by sex and combined sexes for passive tobacco exposure are presented in Table 6. Of the 139 incident cases of lung cancer in 2012 estimated to be among never smokers, 9 could be attributed to passive tobacco exposure (Table 5).

\section{Interpretation}

Results of these analyses suggest that $15.7 \%(n=2485)$ of all incident cases of cancer in Alberta in 2012 were attributable to active tobacco smoking. In addition, 3 cases of lung can- 


\begin{tabular}{|c|c|c|c|c|c|c|c|c|c|}
\hline \multirow[b]{2}{*}{$\begin{array}{l}\text { Exposure; } \\
\text { cancer site† }\end{array}$} & \multicolumn{3}{|c|}{ Total } & \multicolumn{3}{|c|}{ Men } & \multicolumn{3}{|c|}{ Women } \\
\hline & $\begin{array}{l}\text { Observed } \\
\text { casesł }\end{array}$ & $\begin{array}{l}\text { Excess } \\
\text { attributable } \\
\text { cases§ }\end{array}$ & $\begin{array}{c}\% \\
\text { attributableף }\end{array}$ & $\begin{array}{c}\text { Observed } \\
\text { cases }\end{array}$ & $\begin{array}{l}\text { Excess } \\
\text { attributable } \\
\text { cases }\end{array}$ & $\begin{array}{c}\% \\
\text { attributable }\end{array}$ & $\begin{array}{c}\text { Observed } \\
\text { cases }\end{array}$ & $\begin{array}{l}\text { Excess } \\
\text { attributable } \\
\text { cases }\end{array}$ & $\begin{array}{c}\% \\
\text { attributable }\end{array}$ \\
\hline \multicolumn{10}{|l|}{ Active tobacco smoking } \\
\hline Lung & 1952 & 1475 & 75.6 & 953 & 739 & 77.5 & 999 & 733 & 73.4 \\
\hline Colorectum & 1951 & 223 & 11.4 & 1105 & 141 & 12.7 & 846 & 85 & 10.1 \\
\hline Kidney & 482 & 95 & 19.7 & 326 & 69 & 21.1 & 156 & 28 & 18 \\
\hline Pancreas & 379 & 73 & 19.3 & 171 & 36 & 20.9 & 208 & 37 & 17.7 \\
\hline Oral cavity and pharynx & 373 & 159 & 42.6 & 273 & 123 & 45 & 100 & 39 & 38.7 \\
\hline Bladder & 354 & 147 & 41.6 & 280 & 125 & 44.7 & 74 & 28 & 37.8 \\
\hline Stomach & 255 & 53 & 20.9 & 158 & 36 & 23 & 97 & 18 & 18.9 \\
\hline Liver & 217 & 57 & 26.4 & 148 & 42 & 28.6 & 69 & 17 & 24.1 \\
\hline Ovary & 189 & 7 & 3.6 & & & & 189 & 7 & 3.6 \\
\hline Esophagus & 183 & 83 & 45.4 & 151 & 73 & 48.1 & 32 & 14 & 42.8 \\
\hline Myeloid leukemia & 176 & 22 & 12.3 & 99 & 14 & 13.8 & 77 & 8 & 10.8 \\
\hline Cervix & 132 & 34 & 25.9 & & & & 132 & 34 & 25.9 \\
\hline Larynx & 76 & 56 & 74.3 & 64 & 49 & 76.5 & 12 & 8 & 70.8 \\
\hline All associated cancers & 6719 & 2485 & 37.0 & 3728 & 1446 & 38.8 & 2991 & 1056 & 35.3 \\
\hline All cancers & 15836 & 2485 & 15.7 & 8155 & 1446 & 17.7 & 7681 & 1056 & 13.7 \\
\hline \multicolumn{10}{|c|}{ Passive tobacco exposure } \\
\hline Lung & 195 & 9 & 5.2 & 95 & 5 & 5.9 & 100 & 4 & 4.7 \\
\hline All associated cancers ${ }^{* *}$ & 195 & 9 & 5.2 & 95 & 5 & 5.9 & 100 & 4 & 4.7 \\
\hline All cancers†† & 15836 & 9 & - & 8155 & 5 & - & 7681 & 4 & - \\
\hline \multicolumn{10}{|c|}{$\begin{array}{l}\text { *Data on prevalence of tobacco exposure from the Canadian Community Health Survey. } \\
\text { tCancer incidence data for the year } 2012 \text { from the Alberta Cancer Registry. } \\
\text { †Number of observed cancer cases in Alberta in } 2012 \text { at individual cancer sites. } \\
\text { \$Number of cancer cases at individual cancer sites that can be attributed to active or passive tobacco exposure. } \\
\text { १Proportion of cancers at individual cancer sites attributable to active or passive tobacco exposure. } \\
\text { **All associated cancers includes all cancers known to be associated with active or passive tobacco exposure (as listed in the current table). } \\
\text { †All cancers includes all incident cancer cases in Alberta for all ages in } 2012 \text {. }\end{array}$} \\
\hline
\end{tabular}

cer in never smokers were attributable to passive tobacco exposure.

Recently, Cancer Care Ontario conducted a similar analysis for the province of Ontario ${ }^{39}$ also using the CCHS cycle 1.1 (2000/01) for prevalence estimates of tobacco use in Ontario. In the year 2000, 24.5\% of people aged 12 years and older in Ontario were current daily or occasional smokers, which was $3.1 \%$ lower than the prevalence in Alberta. These investigators found that an estimated $15 \%$ of new cancer cases $(n=9800)$ diagnosed in 2009 were attributable to active tobacco smoking, which is comparable to our estimate of $15.7 \%$. Similar to the Alberta estimates, the largest population attributable risk estimates in the Ontario study were for cancers of the larynx (73\%), lung and bronchus (71\%), esophagus (41\%), and lip, oral cavity and pharynx (39\%). For all cancer sites applicable to both sexes, population attributable risk estimates were greater for men than for women, with the exception of pancreatic cancer, which was also observed in the Alberta analysis. ${ }^{39}$ No analyses were completed for passive smoke exposure in the Ontario study.
Using smoking prevalence data from the 2010 National Health Interview Survey, Jacobs and colleagues ${ }^{45}$ estimated that $31.7 \%(n=568191)$ of all cancer deaths in the United States in 2010 were attributable to cigarette smoking, which is almost twice the proportion found in our analysis. However, given that the outcome of death from cancer was examined for the American study, whereas cancer incidence was used in our work, these differences are expected because the cancers most associated with active tobacco smoking are the major contributors to cancer-related death.

Parkin determined that $86 \%(n=34599)$ of lung cancer cases in the United Kingdom could be attributed to exposure to tobacco smoke, of which $97 \%$ were attributable to current or former active smoking. ${ }^{40}$ Furthermore, tobacco exposure accounted for $19 \%(n=60837)$ of all new cancer cases in the UK. This overall estimate is higher than the $15.7 \%$ found in the current analysis, which could be explained by both active and passive (at work and home) tobacco exposure being accounted for in the overall analysis. In addition, prevalence 


\begin{tabular}{|c|c|c|c|c|}
\hline $\begin{array}{l}\text { Age at } \\
\text { exposure }\end{array}$ & $\begin{array}{l}\text { Age at } \\
\text { outcome }\end{array}$ & Obs. ${ }^{*}$ & $\begin{array}{c}\text { PAR } \\
(95 \% \mathrm{Cl})\end{array}$ & $\begin{array}{c}\text { EAC } \\
(95 \% \mathrm{Cl})\end{array}$ \\
\hline \multicolumn{5}{|l|}{ Men } \\
\hline $20-34$ & $30-44$ & $<5$ & $11.7(8.3-15.2)$ & - \\
\hline $35-49$ & $45-59$ & 14 & $7.9(5.4-10.7)$ & $1(1-2)$ \\
\hline $50-64$ & $60-74$ & 47 & $6.6(4.3-9.3)$ & $3(2-5)$ \\
\hline$\geq 65$ & $\geq 75$ & 33 & $3.6(2.0-5.7)$ & $1(1-2)$ \\
\hline Total & Total & $<99$ & & 5 \\
\hline \multicolumn{5}{|l|}{ Women } \\
\hline $20-34$ & $30-44$ & $<5$ & $8.1(5.7-10.8)$ & - \\
\hline $35-49$ & $45-59$ & 17 & $6.6(4.3-9.2)$ & $1(1-2)$ \\
\hline $50-64$ & $60-74$ & 48 & $4.7(3.0-6.7)$ & $2(1-3)$ \\
\hline$\geq 65$ & $\geq 75$ & 34 & $3.7(2.4-5.4)$ & $1(1-2)$ \\
\hline Total & Total & $<104$ & & 4 \\
\hline \multicolumn{5}{|l|}{ Total } \\
\hline 20-34 & $30-44$ & $<5$ & $9.9(7.1-12.9)$ & - \\
\hline $35-49$ & $45-59$ & 31 & 7.3 (5.0-9.6) & $2(1-3)$ \\
\hline $50-64$ & $60-74$ & 95 & $5.5(3.7-7.4)$ & $5(3-7)$ \\
\hline$\geq 65$ & $\geq 75$ & 67 & $3.7(2.4-5.2)$ & $2(2-4)$ \\
\hline Total & Total & $<198$ & & 9 \\
\hline \multicolumn{5}{|c|}{$\begin{array}{l}\text { Note: } \mathrm{Cl}=\text { confidence interval, } \mathrm{EAC}=\text { excess attributable cases due to exposure, } \\
\text { Obs. }=\text { total number of observed cases per age-sex group, PAR = population } \\
\text { attributable risk. } \\
{ }^{*} \text { Cell counts of less than } 5 \text { for observed cases were suppressed to comply with } \\
\text { confidentiality requirements. }\end{array}$} \\
\hline
\end{tabular}

estimates for the UK study were not available, so an approximation based on data from the American Cancer Society's second Cancer Prevention Study was used. Differences in prevalence estimates between the Alberta and UK populations could explain the difference observed in population attributable risk.

\section{Limitations}

Because our sensitivity analysis showed very low prevalence of Albertans smoking tobacco products other than cigarettes, for active smoking, population attributable risks were estimated only for tobacco exposure through cigarettes. Information on occupational passive tobacco exposure was not available for the current study. Smoking in public places and workplaces in Alberta was legal until the Tobacco Reduction Act became law in 2008. Parkin ${ }^{40}$ also considered passive tobacco exposure in his analyses. About $15 \%$ of lung cancers were shown to be attributable to passive tobacco smoking either at home from a spouse or at work. Because no prevalence data were available for occupational passive tobacco smoke exposure in Alberta, similar estimates related to occupational exposure could not be made. In 2012, Sisti and Boffetta conducted a study examining the proportion of lung cancer in never smokers attributable to several risk factors, including second-hand smoke exposure. ${ }^{46}$ An estimated $6 \%$ of lung cancers in women and $8 \%$ in men in
2008 were attributed to second-hand smoke exposure in North America. When the source of exposure was examined separately, results showed highest population attributable risk estimates for exposure at the workplace compared with exposure at home, which could explain why our population attributable risk estimates for passive tobacco exposure are much smaller.

\section{Conclusion}

By examining a wide range of cancer sites, we were able to show which cancers are most influenced by tobacco exposure using prevalence estimates specific to Alberta.

Our results estimate that about $15.7 \%$ of incident cancer cases, translating to 2485 cancer cases in Alberta in 2012, were attributable to current or former active tobacco smoking. Reducing the prevalence of smoking through additional prevention strategies should be a top priority of public health agencies in Alberta, since it could greatly decrease the number of incident cancers observed in Alberta each year.

\section{References}

1. IARC monographs on the evaluation of carcinogenic risks to humans: personal habits and indoor combustions. Lyon (France): International Agency for Research on Cancer (IARC); 2012.

2. Taylor R, Najafi F, Dobson A. Meta-analysis of studies of passive smoking and lung cancer: effects of study type and continent. Int 7 Epidemiol 2007;36:1048-59.

3. Kim CH, Lee YC, Hung RJ, et al. Exposure to secondhand tobacco smoke and lung cancer by histological type: a pooled analysis of the International Lung Cancer Consortium (ILCCO). Int 7 Cancer 2014;135:1918-30.

4. Grundy A, Friedenreich CM, Poirier AE, et al. A methodologic framework to evaluate the number of cancers attributable to lifestyle and environment in Alberta. CMA7 Open 2016;4:E471-8.

5. Boffetta $\mathrm{P}, \mathrm{Clark} \mathrm{S}$, Shen $\mathrm{M}$, et al. Serum cotinine level as predictor of lung cancer risk. Cancer Epidemiol Biomarkers Prev 2006;15:1184-8.

6. Kenfield SA, Wei EK, Stampfer MJ, et al. Comparison of aspects of smoking among the four histological types of lung cancer. Tob Control 2008;17:198-204.

7. Freedman ND, Abnet CC, Leitzmann MF, et al. A prospective study of tobacco, alcohol, and the risk of esophageal and gastric cancer subtypes. Am 7 Epidemiol 2007; 165:1424-33.

8. Yun YH, Jung KW, Bae JM, et al. Cigarette smoking and cancer incidence risk in adult men: National Health Insurance Corporation Study. Cancer Detect Prev 2005;29:15-24.

9. Friborg JT, Yuan JM, Wang R, et al. A prospective study of tobacco and alcohol use as risk factors for pharyngeal carcinomas in Singapore Chinese. Cancer 2007;109:1183-91.

10. Nordlund LA, Carstensen JM, Pershagen G. Cancer incidence in female smokers: a 26-year follow-up. Int 7 Cancer 1997;73:625-8.

11. Jee SH, Samet JM, Ohrr H, et al. Smoking and cancer risk in Korean men and women. Cancer Causes Control 2004;15:341-8.

12. Tran GD, Sun XD, Abnet CC, et al. Prospective study of risk factors for esophageal and gastric cancers in the Linxian general population trial cohort in China. Int 7 Cancer 2005; 113:456-63.

13. Ishiguro S, Sasazuki S, Inoue M, et al. Effect of alcohol consumption, cigarette smoking and flushing response on esophageal cancer risk: a population-based cohort study (JPHC study). Cancer Lett 2009;275:240-6.

14. Lindblad M, Rodriguez LA, Lagergren J. Body mass, tobacco and alcohol and risk of esophageal, gastric cardia, and gastric non-cardia adenocarcinoma among men and women in a nested case-control study. Cancer Causes Control 2005; 16:285-94.

15. Sung NY, Choi KS, Park EC, et al. Smoking, alcohol and gastric cancer risk in Korean men: the National Health Insurance Corporation Study. Br 7 Cancer 2007:97:700-4

16. Yang HI, Lu SN, Liaw YF, et al. Hepatitis B e antigen and the risk of hepatocellular carcinoma. N Engl 7 Med 2002;347:168-74.

17. Basa GF, Hirayama T, Cruz-Basa AG. Cancer epidemiology in the Philippines. Natl Cancer Inst Monogr 1977;47:45-56.

18. Friedman GD, van den Eeden SK. Risk factors for pancreatic cancer: an exploratory study. Int 7 Epidemiol 1993;22:30-7.

19. Tsoi KKF, Pau CYY, Wu WKK, et al. Cigarette smoking and the risk of colorectal cancer: a meta-analysis of prospective cohort studies. Clin Gastroenterol Hepatol 2009; 7:682-688.e1-5

20. Hannan LM, Jacobs EJ, Thun MJ. The association between cigarette smoking and risk of colorectal cancer in a large prospective cohort from the United States. Cancer Epidemiol Biomarkers Prev 2009;18:3362-7. 
21. Terry PD, Miller AB, Jones JG, et al. Cigarette smoking and the risk of invasive epithelial ovarian cancer in a prospective cohort study. Eur 7 Cancer 2003;39:1157-64.

22. Tworoger SS, Gertig DM, Gates MA, et al. Caffeine, alcohol, smoking, and the risk of incident epithelial ovarian cancer. Cancer 2008;112:1169-77.

23. Gram IT, Braaten T, Adami HO, et al. Cigarette smoking and risk of borderline and invasive epithelial ovarian cancer. Int 7 Cancer 2008;122:647-52.

24. Kapeu AS, Luostarinen T, Jellum E, et al. Is smoking an independent risk factor for invasive cervical cancer? A nested case-control study within Nordic biobanks. Am 7 Epidemiol 2009;169:480-8

25. McIntyre-Seltman K, Castle PE, Guido R, et al. Smoking is a risk factor for cervical intraepithelial neoplasia grade 3 among oncogenic human papillomavirus DNApositive women with equivocal or mildly abnormal cytology. Cancer Epidemiol Biomarkers Prev 2005; $14: 1165-70$.

26. Schiffman MH, Bauer HM, Hoover RN, et al. Epidemiologic evidence showing that human papillomavirus infection causes most cervical intraepithelial neoplasia. 7 Natl Cancer Inst 1993;85:958-64

27. Chow WH, Gridley G, Fraumeni JF Jr, et al. Obesity, hypertension, and the risk of kidney cancer in men. NEngl F Med 2000;343:1305-11.

28. Engeland A, Andersen A, Haldorsen T, et al. Smoking habits and risk of cancers other than lung cancer: 28 years' follow-up of 26,000 Norwegian men and women. Cancer Causes Control 1996;7:497-506.

29. Fernberg P, Odenbro A, Bellocco R, et al. Tobacco use, body mass index, and the risk of leukemia and multiple myeloma: a nationwide cohort study in Sweden. Cancer Res 2007;67:5983-6.

30. Alberg AJ, Kouzis A, Genkinger JM, et al. A prospective cohort study of bladder cancer risk in relation to active cigarette smoking and household exposure to secondhand cigarette smoke. Am 7 Epidemiol 2007;165:660-6.

31. Tulinius H, Sigfusson N, Sigvaldason H, et al. Risk factors for malignant diseases: a cohort study on a population of 22,946 Icelanders. Cancer Epidemiol Biomarkers Prev 1997;6:863-73.

32. Yuan JM, Ross RK, Wang XL, et al. Morbidity and mortality in relation to cigarette smoking in Shanghai, China. A prospective male cohort study. $7 A M A$ 1996;275:1646-50.

33. Veglia F, Vineis P, Overvad K, et al. Occupational exposures, environmental tobacco smoke, and lung cancer. Epidemiology 2007;18:769-75.

34. Vineis P, Airoldi L, Veglia F, et al. Environmental tobacco smoke and risk of respiratory cancer and chronic obstructive pulmonary disease in former smokers and never smokers in the EPIC prospective study. BM7 2005;330:277.

35. Kurahashi N, Inoue M, Liu Y, et al. Passive smoking and lung cancer in Japanese non-smoking women: a prospective study. Int 7 Cancer 2008;122:653-7.

36. Health indicator profile, annual estimates, by age group and sex, Canada, provinces, territories, health regions. (2013 boundaries) and Peer Groups, Occasional. Ottawa: Statistics Canada; 2013.

37. Béland Y. Canadian community health survey - methodological overview. Health Rep 2002;13:9-14.

38. Parkin DM. 1. The fraction of cancer attributable to lifestyle and environmental factors in the UK in 2010. Br 7 Cancer 2011;105(Suppl 2):S2-5.

39. Cancer risk factors in Ontario: tobacco. Toronto: Cancer Care Ontario; 2014

40. Parkin DM. 2. Tobacco-attributable cancer burden in the UK in 2010. Br 7 Cancer 2011;105(Suppl 2):S6-13.

41. Bryant H, Robson PJ, Ullman R, et al. Population-based cohort development in Alberta, Canada: a feasibility study. Chronic Dis Can 2006;27:51-9.
42. Sun S, Schiller JH, Gazdar AF. Lung cancer in never smokers - a different disease. Nat Rev Cancer 2007:7:778-90.

43. Gandini S, Botteri E, Iodice S, et al. Tobacco smoking and cancer: a meta-analysis Int 7 Cancer 2008; 122:155-64.

44. Beral V, Gaitskell K, Hermon C, et al.; Collaborative Group on Epidemiologica Studies of Ovarian Cancer. Ovarian cancer and smoking: individual participant meta-analysis including 28114 women with ovarian cancer from 51 epidemiological studies. Lancet 2012;13:946-56.

45. Jacobs EJ, Newton CC, Carter BD, et al. What proportion of cancer deaths in the contemporary United States is attributable to cigarette smoking? Ann Epidemiol 2015;25:179-182.e1.

46. Sisti J, Boffetta P. What proportion of lung cancer in never-smokers can be attributed to known risk factors? Int 7 Cancer 2012;131:265-75.

Affiliations: Department of Cancer Epidemiology and Prevention Research (Poirier, Grundy, Khandwala, Tamminen, Friedenreich, Brenner) CancerControl Alberta, Alberta Health Services; Alberta Cancer Prevention Legacy Fund, Population, Public and Aboriginal Health, Alberta Health Services; Department of Oncology (Friedenreich, Brenner), Cumming School of Medicine, University of Calgary; Department of Community Health Sciences (Friedenreich, Brenner), Cumming School of Medicine, University of Calgary, Calgary, Alta.

Contributors: Christine Friedenreich and Darren Brenner were responsible for the study conception. Anne Grundy, Christine Friedenreich, Darren Brenner, Farah Khandwala and Abbey Poirier contributed substantially to the study design and interpretation of the data. Farah Khandwala completed the analysis. Sierra Tamminen and Abbey Poirier were responsible for acquisition of the data. Abbey Poirier, Anne Grundy, Christine Friedenreich, Farah Khandwala, Sierra Tamminen and Darren Brenner prepared the manuscript, gave final approval of this version to be published and agreed to be guarantors of the work.

Acknowledgements: his project was funded by the Alberta Cancer Prevention Legacy Fund. Christine Friedenreich is supported by an Alberta Innovates-Health Solutions Health Senior Scholar Award and the Alberta Cancer Foundation Weekend to End Women's Cancers Breast Cancer Chair at the University of Calgary. Darren Brenner is supported by a Career Development Award in Prevention from the Canadian Cancer Society Research Institute. The authors gratefully acknowledge Dr. Laura McDougall from the Alberta Cancer Prevention Legacy Fund for her support and guidance. They also thank Bethany Kaposhi and Lorraine Shack from the Alberta Cancer Registry for providing cancer incidence data, the Department of Data Integration, Measurement and Reporting at Alberta Health Services for access to CCHS data and Eileen Shaw for critical review of this manuscript.

Supplemental information: For reviewer comments and the original submission of this manuscript, please see www.cmajopen.ca/content/4/4 E578/suppl/DC1 